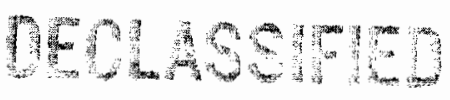

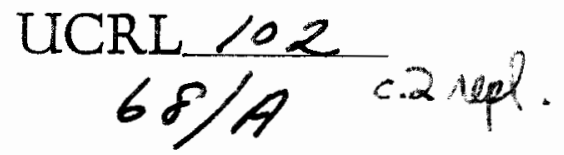

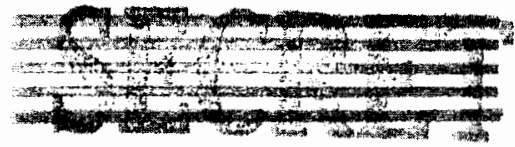

UNIVERSITY OF

CALIFORNIA

REOEIVED

LAWRENCE

BERKELEY LABORATORY

Radiation

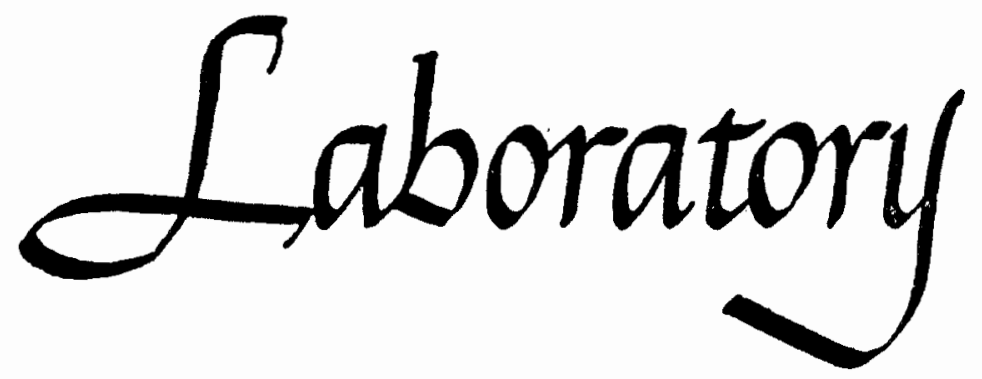

TWO-WEEK LOAN COPY

This is a Library Circulating Copy

which may be borrowed for two weeks.

BERKELEY, CALIFORNIA

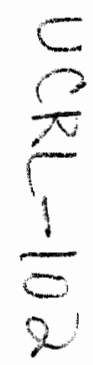




\section{UPIDERSITY OF CAIIHCRNTA}

\section{RALIATON LABCRATOYY}

Cover Sheet

Do riot romove
IDPX NC. KCQR - L2

This a do mont contains paces and nlates of finures.

Thin copylad of $\mathscr{Y}$. series

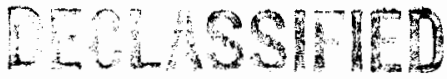

issued to:

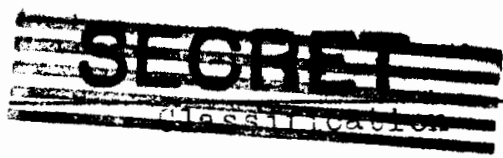

Jach person who recejved this document must sign the cover fhet in tho space below.

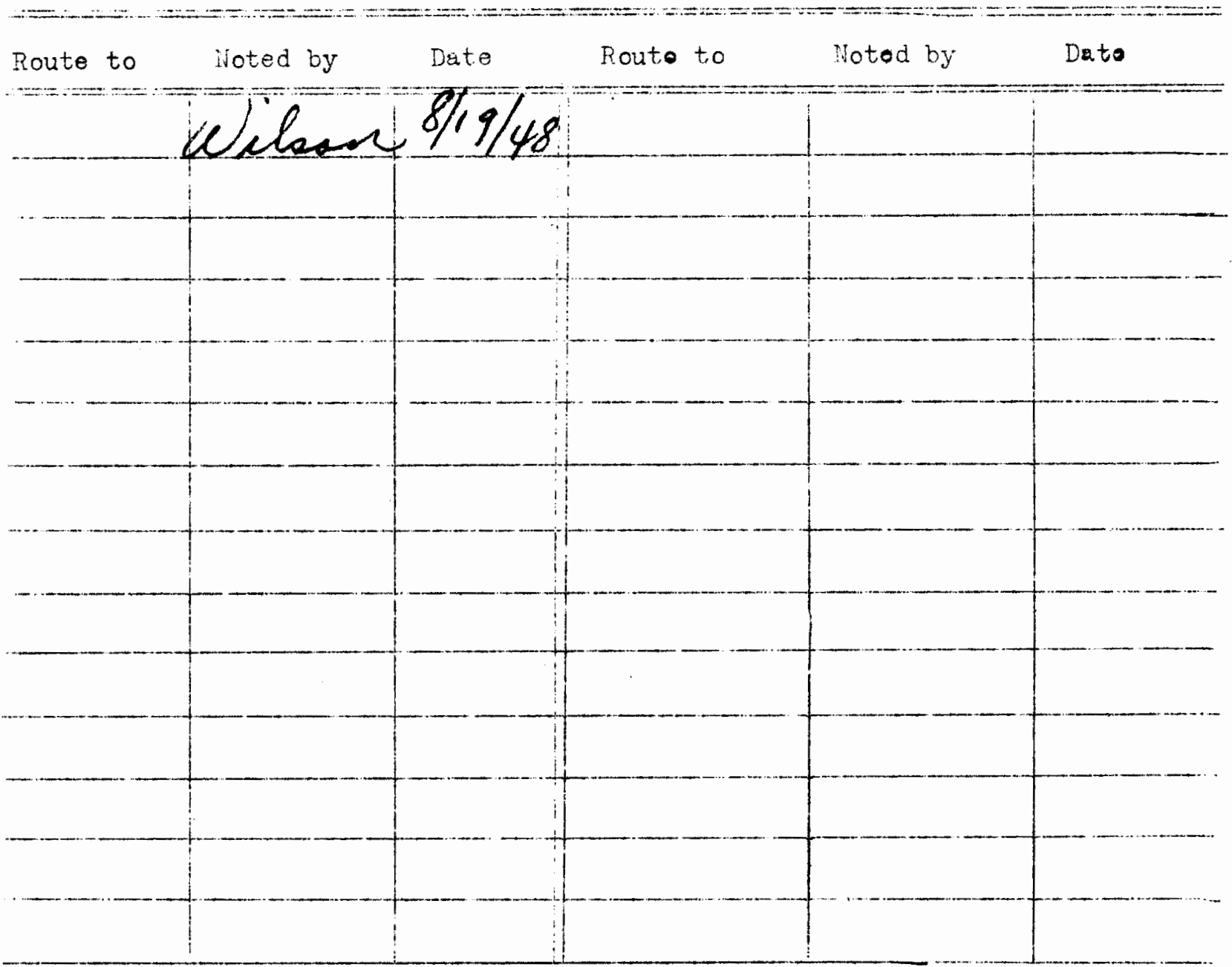

$\mathrm{R}-4 \mathrm{I}$ 


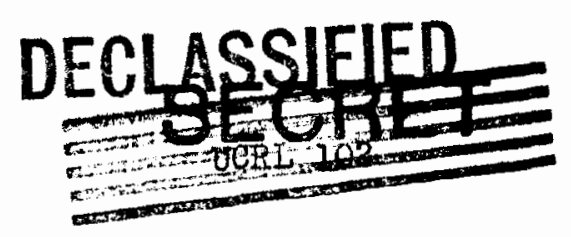

UNIVERSITY OF CALIFORNIA

RADIATION LABORATORY

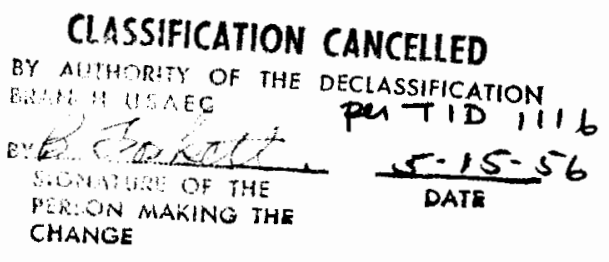

ELECTRONIC STRUCTURE OF THE HEAVIEST ELEMENTS

By G. T. Seaborg

July 10, 1948

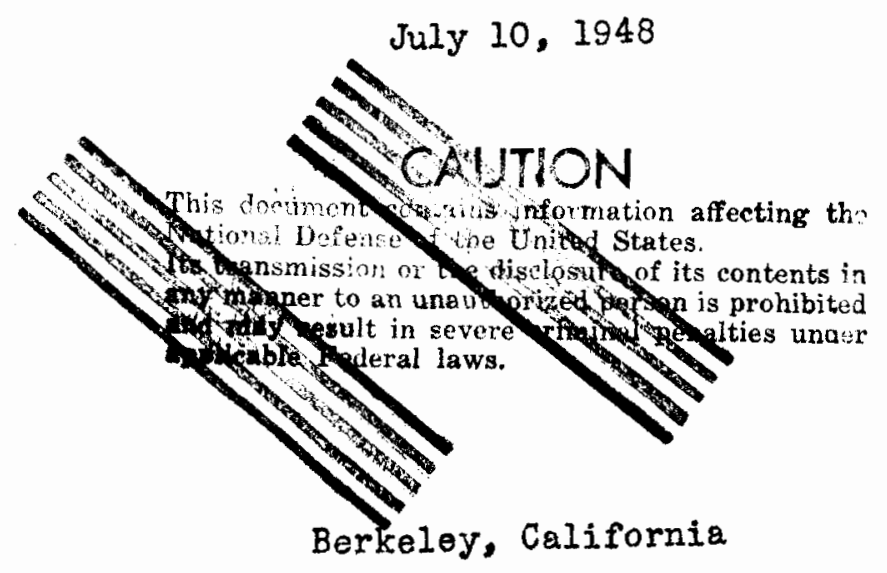




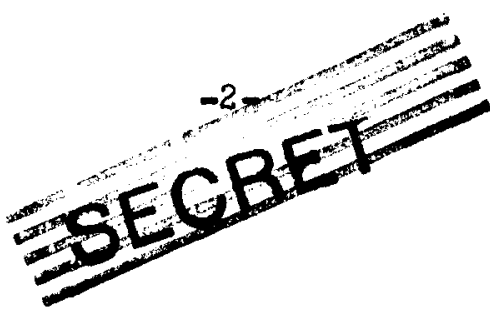

UCRL 102

Chemis try-Transuranic

Elements

Standard Distribution

No. of Copies

Argonne National Laboratory

$1-10$

Atomic Energy Commission. Washington

$11-12$

Brookhaven National Laboratory

$13-20$

General Electrio Company

$21-24$

Hanford Directed Operations

25-31

Iowa State College

32

Kellex Corporation

$33-34$

Los Alamos

$35-37$

Naval Radiological Defense Laboratory

38

NEPA

New York Directed Operations

39

$40-41$

Oak Ridge National Laboratory

$42-49$

Patent Advisor, Washington

50

Technical Information Division, ORDO

$51-65$

University of California, Information Division

Chemistry Department

$66-70$

$71-75$

University of Rochester

Office of Chicago Directed Operations

76-77

78 
UCRI -102

July 19, 1948

Pagc 3

ELECTRONIC STRUCTURE OF THE HEAVIEST ELEMENTS

B.y G. T. Seaborg

\section{Table of Contents}

Abstract . . . . . . . . . . . . . . 4 4

I. Historical fackground . . . . . . . . . . . . 5

A. Bofore tho Discovery of tho Transuranium Tioments : 5

B. Aftor tho Discovory or tho Transuranium Tlemonts. . 8

II. Actinido concopt ................ 9

A. Goncral . . . .............. 9

B. Chomical rvidence . . . . . . . . . . . 10

C. Absorption spoctra in Aqucous Solution and crystals . I8

D. Crystallocraplic Data ............. 20

E. Magnetic Suscoptibility Data..........22

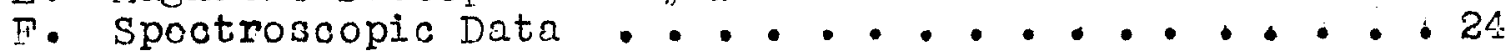

III. Corrclations and Doductions . . . . . . . . 25

A. Electronic Configurations . . . . . . . . . 25

B. Possible Deductions without Data on Transuranium Tlemonts . . . . . . . . . . 28

C. Position in Poriodic Tablo and Nomenclaturo ...229

D. Prodicted Propertios of Transcurium Elemonts ... 31

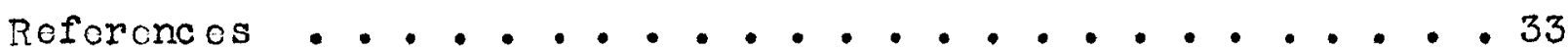




\section{ELECTRONIC STRUCTURE OF THE HEATIEST EI EMTNTS}

By Glenn T. Seaborg

\section{Abstract}

All of the available evidence leads to the view that the $5 f$ electron shell is bein? filled in the heaviest elements giving rise to a transition series which begins with actinium in the same sense that the rare earth or "lanthanide" series begins with lanthanum. Such an "actinide" series is suggested on the basis of evidence in the following lines: (1) chemical properties, (2) absorption spectra in aqueous solution and crystals, (3) crystallographic structure data, (4) magnetic susceptibility data and (5) spectroscopic data. The salient point is that the characteristic oxidation state (i.e., the oxidation state exhibited by the member containine seven $5 f$ and presumably also by the member containing fourteen $5 f$ electrons, curium and element 103) is the III state, and the group is placed in the periodic table on this basis. The data also make it possible to give a suggested table of electronic configurations of the ground state of the Saseous atom for each of the elements from actinium to curium inclusive. 
ELECTRONIC STRUCTURE OT THE HEAVIEST ELEMENTS

By Glenn T. Seabors

\section{Historical Background}

A. Before the Discovery of the Transuranium Elements. The intensive study of the heavy elements during the last few years has given information and data which now enable us to make some definite statements as to their electronic structure. The information obtained about the recently discovered synthetic transuranium elements has been particularly useful in this connection, and it is largely on the basis of these new elements that this question is now well understood.

The heaviest natural elements, thorium, protactinium and uranium, of atomic numbers 90,91 and 92 , respectively, lie in corresponding positions just below the 6th perjod "transition" elements, hafnium, tantalum and tunjsten, in which the $5 \mathrm{~d}$ electron shell is being filled. The elements, hafnium, tantalum and tungsten are similar in their chemical properties to the cor responding transition elements in the 5 th period, zirconium, columbium, and molybdenum, in which the $4 \mathrm{~d}$ shell is being filled.

It has long been known that the chemical properties of thorium, protactinium and urantum resemble those of these $4 \mathrm{~d}$ and $5 \mathrm{~d}$ elements and for this reason most of the textbooks and standard works on chemistry and physics in which the electron structure is discussed have accepted the view that it is the $6 \mathrm{~d}$ shell which is being filled. Thus the structure of the elements above racion (element 86) through uranium is written to show the addition of the next two electrons in the $7 \mathrm{~s}$ she 11 for element 87 (francium) and element 
UCRI - 102

Page 6

88 (radium) and addition in the $6 \mathrm{~d}$ shell for the following four -lements, actinium, thorium, protactinium and uranium(I).

Many of the early papers which appeared after N. Bohr's classical work $(2)$ on the quanticed nuclear atom discuss the electronic structure of the heaviest elements. There has bcen general agreement that some type of transition group should begin in the nejghborhood of the se elements, although there has been difference of opinion as to where it begins and as to which electron shells are involved. A number of the earliest publications even have sugsested that this transition series involves the filling of the $5 f$ shell, thus possibly giving riso to a "rare earth" group in a manner analogous to the filling of the $4 f$ shell. This filling of the $4 f^{\prime}$ shell results in the well known group of 14 rare earth elements of atomic numbers 58-71 inclusive, following lanthanum. It is of interest here to note a few of these early and also later suggestions in order to roview the general previous status of this question. Most of these early investigators were of tho opinion that the filling of the $5 f$ shell should begin at some point beyond uranium, that is, beyond the then known elements. In an early paper Bohr ${ }^{(3)}$ sujgested that the addition of the $5 f$ electrons might begin in this region, and in a Bohr-Thomsen type of periodic table he pictured the first entry at the element with atomic number 94. Y. Suguira and H. C. Urey(4) gave calculations indicating that the first entry of the electron into the 5 f shell should occur at element 95. J. C. McLennan, A. B. Melay and $H$. $G$. Smith $(5)$ suggested as an alternative to the filling of the $6 \mathrm{~d}$ shell the possibility that the $5 \mathrm{f}$ shell begins to be occupied in thorium. In a review article, S. Dushman (6) stated 


\section{UCZL -102 \\ Page 7}

it is doubtful that the added electrons enter the $6 \mathrm{~d}$ le vel (thus implying an analogy with cerium, etc.). $\forall \cdot$ Karapetoff( $(7)$ and Ta-You-Vu and s. Coudsmit ${ }^{(8)}$ sugeested that the element with atomic number 93 might be the first in which the $5 f$ shell begins to be filled, while A. von crosse ${ }^{(9)}$ suggested, as a possible alternative to filling of the 6 d shell, the entry of the first electron in the $5 f$ shell with uranium. More recently I. L. QuilI(10) largely for the purpose of illustration, presented periodic table arrangements in which the first $5 f$ electron appears in element number 95 in one case and in elenent number 99 in another. The later calculations of $M$. Coeppert Mayer(11) indicate that the filling of the $5 f$ sholl might begin at protactinium or uranium. $J$. Perrin (12) and on soncral considerations, proposed as a possibility the theory that the first $5 f$ electron appears in thorium and $G$. Villar (13) suggested that some of the chemical evidence supports this viewpoint.

on the basis of his crystallographic work, V. M. Goldschmidt(14) favors the view that the first 5 electron enters at protactinium, tho first element beyond thorium, although he points out the possibility that this may occur either earlier, in thorium, or later, in uranium or in the (at the time unknown) transuranium olements. By analog. with tho namo "lanthanide" sories which he had alroady proposed for the rare earth elements because these 14 elements following lanthanum have lanthanum as their prototypo, ho proposed the name "thoride" serios for the 14 elements following thorium. On the basis of his much more complete crystallosraphic evidence, including especially observations on the transuranium elements, w. H. Zachariasen(15) has come to the samo conclusion. 


\section{TJCRL-102 \\ Page 3}

B. After the Discovery of the Transuranjum lements. The recent discovery of the transuranium elements and the study of their properties, espccially the chemical propertios, have given us a tremendous amount of additional evidence of just the type needed to clarify this problom. As it turns out, it is in the transuranium eloments that the really definitive chomical properties, from the standpoint of placing the heaviest clements in the ocriodic table, first appear. Tho first bost definite cvidence that the $5 f$ shell undergoes filling in this hoavg rogion came from the tracer chemical observations of E. M. McMillan and P. H. Abelson (16) on element 93 (neptunium); upon their discovery of this, the first transuranium element, they wero able to show definitely that it rosembles uranium in its chemical properties and bears no resemblance to rhonium, the element immediatoly above it in the periodic table. This excollent exporimontal evidence was interpreted by them to indicate that this now "rare earth" group of similar elemonts starts with uranium. K. Starke(17) and C. G. Bedroag(18) also interprotod the tracer exporiments with eloment 93 as indicating that the first 5 electron comes at element 93, while F. Strassmann and 0 . Hahn (19) felt on thr basis of their tracer cyporiments with this oloment, that jt was difficult to make any doduction. As a rosult of their first tracer experiments with element 94 toscthor with their consideration of the tracer investigations with elemont 93, G. T. Soaborg and A. Mahl (20) in 1942 mad the sugestion that this transition Group might begin as carly as with thorium or actinium.

Since this first tracer work on the transuranium eloments, tho oloments neptunium (atomic numbor 93) and plutonium (atomic 


$$
\begin{aligned}
& \text { TCRL }-102 \\
& \text { Page } 9
\end{aligned}
$$

number 94) now have beon oxtensively invostigatod with substantial, woighablo quantitios. Amoricium (atomic number 95) and curium (atomic number 96) also have been availablo for invostigation, on a more limited scalo, in wojghable quantitios. The recent oxtensive investigations of thorium, protactinium and uranium also have cont ributed to the evidence which is now useful to interprot this question.

\section{Actinicic concept}

A. Genoral. The ovidence now availablo loads to tho dofinito viow that it is the $5 f$ elcctron shell which is being fillod in these hoavicst cloments. Tho ovidence scems sufficient to go furthor than this and to suggest ${ }^{(21)}$ that this rare-earth-liko scios begins with actinium in the samn sense that tho raro oarth or "lanthanide" scries begins with lanthanum. on this basis it might be tormod the "actinide" sories(2I) and the first $5 f$ oloctron might appcar, although not nocossarily, in thorium. The saliont point is that the characteristic oxidation statc (i.c., tho oxication stato oxhibitod by tho member containing soven $5 f$ and presumably also by the mombor containing fourtoon. $5 f$ oloctrons, curium and olement 103 ) is tho ITI stato.

Thore is much ovidonco, all nointing toward this view. Ne will discuss this ovidonce which $1 \mathrm{~s}$ in the following linos: (1) chomical proportios, (2) absorption spoctra in aqueous solution and crystals, (3) crystallocraphic structure data, (4) magnotic susceptibility data and (5) spotroscopic data.

It should bo omphasized that the discussion so far has beon carriod on in a somowhat ovorsimplifiod mannor, bocauso the dotails concerning the possible phrsical or chemical forms in which theso 


\section{UCPI -102 \\ Pag0 10}

elemonts might oxist have a bearing on tho oloctronic structure, as is the case for all tho othor transition groups including tho rare earth clemonts. Thus the number of $5 f$ olcotrons in the atom In tho gascous stato might diffor from that in the motallic stato (which in turn can differ from one phaso to another), and in turn neithnr one of those structures might correspond ciroctly to the chomical proportios. It is tho chomical properties (including absorption spoctra, crystallocraphic data, ctc. on the compounds) which should bo doterminative in placing those olemnts in tho periodic table, just as was thr cose for the raro carth eloments which would bo placod difforontly considering their elcotronic structuros alone.

F. Chemical Evidence. On the basis of an actinide sorios the characteristic oxidation numbor for tho sorios is III, and this, shows up strikingly in the stabilization of the lower oxidation states with increasing atomic number. In soing from uranium to plutonium it beconos incroasingly difficult to offect the oxiration from the $I T$ to the $V T$ stato and, in foct, with amoricium it is imposiblo in aquoous solution to cfect an oxidation to tho VI state. Similarly, it brcomos incroasingly difficult to effect oxidation from tho III to tho IV stato in going from uranium to plutonium, and with americium tho ovidonco indicates that it probably is not possiblo to offect this oxidation in acid solution at all. If this oxidation shovid bo proved possible the indications aro that the potontial is so grcat that tho higher oxidation stato of amoricium is reduced rapidly by wator and connot be maintained in aquoous solution for any groat longth of $t$ imo. These considerations are illustratod by the following table (Tablo I) 
in which the standard oxidation-reduction potentials, reforred to the hwotrogen-hydrogon ion couplo as zoro (sce, for cxample, w. M. Latimor, "oxidation Potentials"(22), aro listed for tho ITI-IV and IV-VI oxidations for those eloments (23).

$$
\text { TABIT, I }
$$

Some oxidation Potentials of the Actinides

(Aquoous Solution, 1 Molal)

\begin{tabular}{|c|c|c|}
\hline \multirow{2}{*}{ Tlemont } & Potontial in Volts \\
\cline { 2 - 3 } & III-IV & IV-VI \\
\hline $92-\mathrm{U}$ & +0.63 & -0.60 \\
$93-\mathrm{INp}$ & -0.14 & -0.94 \\
$94-\mathrm{Pu}$ & -0.95 & -1.11 \\
$95-\mathrm{Am}$ & -2 & -2 \\
\hline
\end{tabular}

Much of tho work dono with curium has of necosity boen

limitod to the tracer scale and therefore it has bocn impossible to make corrosponding quantitative ioductions. This work, how cver, has lod to tho definito qualitative conclusion that it is impossible in aquoous-acid solution to oxidizc curium to tho VI stato and that it is also impossiblo to oxidizo it from tho III to tho IT state. In fact, tho oxporiments of $S$. G. Thompson, I. O. Norgan, R. A. Jamos and I. Porlman (24), in which tracer amounts of curium and amoricium wero subjocted to strong oxidation under alkalino fusion, indicate that it is moro difficult to oxidize curium from tho III to an uppor stato than is tho case for americium, and it may bo impossible to cffect this oxidation at al1. Those oxporiments indicate that amoricium may bo oxidized In alkalino modia, and $c$ an in this mannor be soparated from curium. In fact, I. B. Wernor and I. Porlman (25) woro able to 
$\mathrm{U} T \mathrm{TL}-102$

Pago 12

oxidizo amoricium(III) in $40 \%$ potassium carbonate solution by the uso of the strong oxidizing a cont hypochloritc to an insoluble compound, probably of americium( $(r)$, and honce offect an efficient separation from curium(IJI) which apparontiy is not oxidizod under these severe conditions. The microchemical oxporimonts of Wornor and Porlman(26) with macroscopic concontrations of curium also point towand the existonce of curium solely in the III oxidation state.

This tondoncy toward increasing stabilization of tho lower oxidation states, ospecially tho III state, with incroasing atomic numbor also manifests itsolf notabiy in tho stability of the solid compounds of the various oxidation states of these elements. The bost illustration arisos from a consideration of the solid nonoxygonated halides of theso clomonts. The first possibility of the production of a trifluoride appoars with urenium trifluoride which can bo propared only under drastic roducing conditions and tho stability and caso of roduction to tho trifluorido incroases in going to noptunium and thon to plutorium. Morcovor, while it is rolatively casy to produce uranium hexafluoride, it is moro difficult to produce neptunium hozafluoride and vory difficult or impossiblo to produce and to keop the plutonium hoxafluoride. In the case of americium it has not been possiblo to produc any higher fluoride than the trifluoride.

With rospect to tho othor halidos, it has, in fact, boon impossible to prepare any plutonium or americium chlorido, bromide or iodide of oxidation state higher than III, and it has boon possible to preparo only the chlorido and bromide of noptunium of oxication state IV (in addition to the chloride, bromide and 


\section{UC RI -102 \\ Page 13}

iodido of oxidation state III). In tho caso of uranium it has boon known for some time thet there are chlorides of oxidation state highor than IV and $\varepsilon$ chlorido, bromido and iodice of oxidation state IV. Those considerctions ano woll illustrated in the following tablo (Table II) which lists all of the halicies of uranium, neptunium, plutonium, and amoricium which have boon propored and maintained as stable in the solid state. So far tho chemical ovidenec indicates that it will bo difficult, probably impossible, to proparc any of the non-oxygenated haljdes of cnoricium (and curium) of oxidation statc higher than IJI. In fact, S. Fricd and A. T. Florin (27) hevo troctod $\mathrm{AmF}_{3}$ with fluorine at elovatod temporatures and havo obtained no ovidenco for the formation of a higher fluorido.

This chemical eviajonce indicates that the $5 f$ olcctrons aro loss tightly bound than tho $4 \mathrm{f}$ cloctrons and thoroforo can bo more easily removed by oxidation, as should bo cxpected on the basis of the prodictod lowor binding onergy of $5 f$ as compared to 4.f olcotrons. Thus the III stato of thorium connot oxist in aquoous solution, and until the prosent the IV and III states of protactinium have not bocn observod in aquoous solution, although it soems reosonable that with further study one or both of those states vill bo obscrved. In the caso of solid compounds it socms not impossiblo thet tripositive thorium compounds with one or more of tho hoavior halosens will bo proparod undor rather sovero roducing conditions, and that totra- and tripositivo compounds of protactinium will be proparod as soon as offorts in this diroction are mado. (In fact, Zachanieson(28) and. J. D. Mocullough(29) alroady havo some crystallographic oviconco for a dioxide of 
UCCRI-102

Page 14

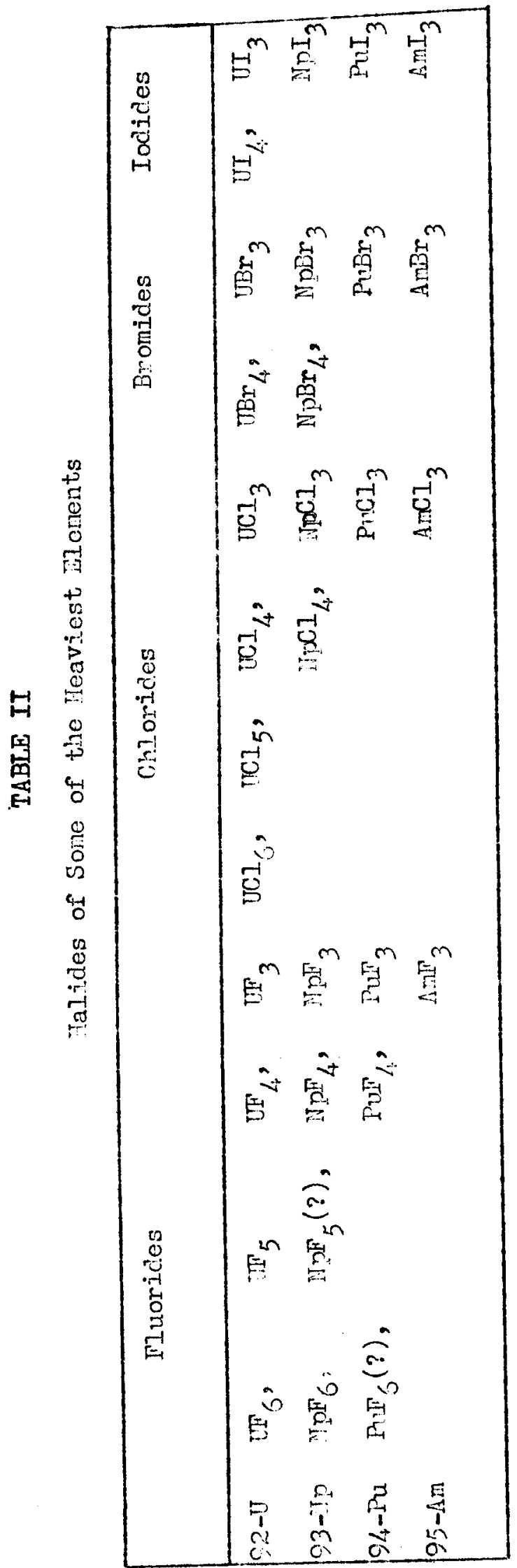


TORI -102

Pago 15

protactinium with the fluorito structuro although this might bo a case of solid solution of two oxidation statos similar to tho solutions studiod by J.K. Mersh $(30,45)$ in the $\mathrm{PrO}_{2}-\mathrm{Cd}_{2} \mathrm{O}_{3}$, $\mathrm{TbO}_{2}-\mathrm{Md}_{2} \mathrm{O}_{3}$ and $\mathrm{Pr}_{2} \mathrm{O}_{3}-\mathrm{PrO}_{2}$ systoms and similnr to the woll known solid solutions in the iron oxide systoms.) Tho charactoristic IV oxidation stato domonstrated by thorium is then analorous to the IV oxidation state of corium and the $V$ state of protactinium is analogous to tho somowhat uncortain $V$ stato of praseodymium $(30,31$ ) From the bohevior of uranium, noptunium and plutonium, it must bo deducod that as meny as throo of tho $5 f$ cloctrons aro givon up fairly roadily. In this connoction it is intcrosting to noto that in tho case of the lanthanide elomonts thorc aro in goneral only two olcctrons (boyond the xrnon structuro) outside of the $4 f$ sholl (soc Tablo VI bolow), although tho porsistont oxidation statc is cortainly tho II stato.

Amoricium should possoss an oxidation stato of II which It would attain through tho prosonco of soven olcctrons in tho $5 f$ sholl in a mannor quito anologous to the II stato of curopium, the olomont immediatoly procodin sadolinium, with its sovon $4 f$ olcotrons. Bocause of the gronter caso in tho nomoval of tho $5 f$ electrons it should requiro a considorably strongor roducing ngent to roduce amricium from tho IIT to the II stato than is tho caso for curopium. It is not impossiblo, howover, but in fact probable, that it will be found that americium con bc reduced and maintained in tho II stato in aquoous solution. Thompson and co-workers (24) havo mado partial scparations of amoricium (presumably as Am(II)) from curium in tracor amounts in aqueous solution by using sodium amaleam as tho roducing agont and carrying omoricium soloctivoly 


$$
\begin{aligned}
& \text { USRL-102 } \\
& \text { Paso } 16
\end{aligned}
$$

with samarium(II) sulfatc, and in addition by using barium as roducing ajont and carrying omcricium scloctivoly with barium chloride from concontrated hydrochloric acid solution. It is intorosting to noto as woll that Amo has boon preparod(32) by tronting amoricium oxice with hycro;on at $800^{\circ} \mathrm{C}$ lalthough somo impurity may have becn rosponsible for tho roduction horo). Curium with its sevon $5 f$ eloctrons should oxhibit the III stato oxclusively and all of the ovidence, obtainod both from tracor and macroscopic quentitios, indicatos that this is tho caso.

The following tablo (Tnblo III) summarizes the known oxidation statos of the lanthonido and actinido clomonts in such a way as to bring out tho analogy botwoon tho two groups and to shaw the groator oaso of ozidation for tho mombers of tho lattor group. The uncortain statos aro dosignotor with parcnthosos.

TARI IIT

\begin{tabular}{|c|c|c|c|c|c|c|c|c|c|}
\hline At. No. & 57 & 58 & 59 & 60 & 61 & 62 & 63 & 64 & 65 \\
\hline Iemont & La & $\mathrm{Co}$ & $\mathrm{Pr}$ & Md & $\mathrm{Pm}$ & $\mathrm{Sm}$ & $\mathbb{M} u$ & $\mathrm{Gd}$ & $\mathrm{Tb}$ \\
\hline \multirow[t]{4}{*}{ oxid. States } & & & & & & 2 & 2 & & \\
\hline & 3 & 3 & 3 & 3 & 3 & 3 & 3 & 3 & 3 \\
\hline & & 4 & 4 & (4) & & & & & 4 \\
\hline & & & 5 & & & & & & \\
\hline At. NO. & 39 & 90 & 91 & 92 & 93 & 94 & 95 & 96 & \\
\hline Element & $A C$ & Th & $\mathrm{Pa}$ & U & $\mathbb{N P}$ & Pu & $\mathrm{Am}$ & $\mathrm{cm}$ & \\
\hline \multirow[t]{5}{*}{ Oxid. Statos } & & & & & & & 2 & & \\
\hline & 3 & & & 3 & 3 & 3 & 3 & 3 & \\
\hline & & 4 & (4) & 4 & 4 & 4 & & & \\
\hline & & & 5 & 5 & 5 & 5 & (5) & & \\
\hline & & & & 6 & 6 & 6 & & & \\
\hline
\end{tabular}

oxidation States of Tonthnnide and Actinide Elemonts 


\section{UCRL $-1 C 2$ \\ Pago 17}

The motals of the eloments thorium to amoricium inclusive have boen propared and thoir proportios studicd and theso boar a striking rosemblance to the metals of tho raro oarth elements. All of thom aro highly olectropositive, and to about the same degroc, which is a similarity to the raro oarth motals and a differonce from tho corrosponding $5 d$ olemonts, hafnium (olomont 72 ) to iridium (olemont 77) inclusive, in which the olcctropositive charactor of hafnium is lost as 5d oloctrons are addod in going toward iridium. Anothor romarkable roscmblance to the roro oarth olomonts lics in tho donsitios of the motals. Both amcricium(33) and tho analogous $4 f$ oloment, ouropium( ${ }^{(34)}$, hrvo donsitios much lowe $r$ than thoir noighboring oloments. Thus those motals socm to have rodiumlike or barium-like structures, with abnormally high radii and analogous eloctronic structures. This analogy in tho donsitios is show in Tablo IV whero tho donsitios (of tho forms of the metals which aro stablo at room tomporaturo) aro listod $(34,35)$. TABI' IV

Densities of Room Trmperature Forms of Some Lanthonide and Actinide Motals

\begin{tabular}{|lccccc|}
\hline At. No. & 60 & 61 & 62 & 63 & 64 \\
Elemont & Nd & Pm & Sm & Eu & Gd \\
Density & 7.00 & & 6.93 & 5.24 & 7.95 \\
\hline At. No. & 92 & 93 & 94 & 95 & 96 \\
Element & $\mathrm{U}$ & $\mathrm{Np}$ & $\mathrm{Pu}$ & $\mathrm{Am}$ & $\mathrm{Cm}$ \\
Donsity & 19.0 & 19.7 & 19.8 &. .11 & \\
\hline
\end{tabular}

A comparison with tungston, rhonium, osmium and iridium brings forth no such analogy. 
c. Absorption spcetra in Aqucous Solution and crystals. One of the charactoristic proportios of the clements of the lanthanide sories, a property which dopends upon the $4 \mathrm{f}$ olcctrons, is thoir sharp absorption bands, to a lorec cxtent in the visiblo spcctrum. This absorption is duo to tronsitions involvinj tho $4 \mathrm{f}$ cloctrons and tho sharpnoss is a consoquonec of tho shiclding of those, both in the ground and oxcitcd states, by oloctrons in tho outor sholls. The invostigations of this typo with tho olomonts uronium, noptunium, plutonium, amoricium and curium havo shown a striking similarity in this property to tho raro oarths, which is furthor ovidonec that wo aro docline with $5 f$ cloctrons. The cnalogy botwocn the raro corths ard uranium( $I^{T}$ ) in this property ras noticod by Goldschmidt ${ }^{(36)}$ and botwoon tho raro oarths and uranium(III) and (IV) by T.Thraim and M. Mozoner(37) mony yoars ago. This similarity botwon tho actinido and tho lanthonido oloments is moro than qualitative in that the senoral comploxity of the $a b-$ sorption picture undergocs analojous simplification as we approach the midalo of tho two scries, that is, as wo aporoach the elomonts gadolinium and curium, with thoir scven $4 f$ or $5 f$ olectrons. Unfortunatoly, up to tho prosent the most extonsive work on tho absorption of uranium and tho transuranium olements has boon dono in solution, whore much of the sharpnoss is lost, and with instrumonts of not very high rosolving powcr. The aquoous solution $a b-$ sorption spoctra of the tripositivo actinidos, takon from various sourcos on the Plutonium Project (38) aro shom in Fig. 1, whoro the corrospondins spoctra of tho raro carth oloments also aro shown for purposos of comprrison. Although the sbsorption curves of . Prandtl and K. Schoinor(39) aro availablo for comparison, 
this work was not done under conditions comprrable to thoso under which the work on tho actinidos was dono. Thorofore, D. C. Stcwart(40) has moasured the absorption spectra of the raro ocrth clomonts undor com r.rablo conditions and his results are also givon in Fis. 1. Tho proliminary rosults of P. M. Lontz and G. W. Parkor (4I) on the absorption spoctrum of promothium (olomont 61) aro also includod. It appoars that as we approach tho middlo of tho two scrios (i.o., as wo cpprocoh tho olomonts gadolinium and curium) tho ground statos involving tho sovon f electrons lio vory dofinitoly bolow the noxt highor statos, loarin, to morgy ifforonos of a sufficiont magnitudo to cousc tho main absorption to fall outside of the viajblo in tho ultroviolot region.

Tho bost method for tho comparison of tho absorption spoctra of tho two groups of oloments is to compare the spoctra obtainod with crystals, whero tho absorption lines aro known to bo vory sharp for tho raro oarth olomonts on the basis of a lango numbor of moasuroments with mony of thoso clemonts. Such moasuromonts are underway for a number of tronsuranium clemonts and tho rosults so far indicatc striking anclogics. S. Frood and F. Loitz(42) havo moasurod tho absorption spoctrum of solid amoricium trichloride and thoy find sharp linos, of tho ordor of one to fivo Angstroms wido, which is a width comparablo with tho sharpost raro carth spcotra. In fact tho sharpnoss in tho spoctra(42) of amcricium chloride and amoricium bromide is so extrome, at room tcmpcraturc and at $77^{\circ} \mathrm{K}$., that only the tripositivo ouropium ion is comporable; since tho absorption spectrum of the latter originatos from 0 ground stato involving six $4 f$ cloctrons, it scoms vory likoly that tho basic stato of tripositivo amoricium contains 
UCRL -102

Pago 20

six $5 f$ clectrons. They (42) also monsured tho absorption spectra at room temperaturo and at $77^{\circ} \mathrm{K}$ of urcnium totrachlorido, neptunium totrachlorido and plutonium trichlorido and the sharpnoss of tho linos indicatos that tho loast stablo oloctrons of thoso ions aro in tho inner $5 f$ she 11 in tho activatod as woll as in the basic cloctronic statos.

D. Crystallographic Data. As mentionod abovo, crystallocraphic evidonce in adition points to the filling of tho $5 f$ shcll In this noighborhood of hoavy olomonts. Somo ycars ago, foldschmidt $(14,43)$ had alroady notiecd the isomorphism of Tho and $\mathrm{TO}_{2}$, and tho decroasc in size in going to $\mathrm{TO}_{2}$, and hec intorpretod this to indicato the prosonco of $5 f$ oloctrons in uranium. Tho observation of zachariason(28) of tho isomorphism of tho compounds ThO2, $\mathrm{PaO}_{2}, \mathrm{UO}_{2}, \mathrm{NPO}_{2}, \mathrm{PuO}_{2}$ and $\mathrm{AmO}_{2}(44)$, together with his obsorvation of tho rogular docronso in radius of the motalic ion in those oxidos, has bocn interprotod by him to bo cxcollont ovidonco that tho olcctrons aro going into tho $5 f$ sholl. (In this scrios, however, the lattice constants of the $\mathrm{PaO}_{2}(28,29)$ and $\mathrm{AmO}_{2}(45)$ do not fit porfoctly into the rogular pottorn for docroaso in atomic radius of tho motallic ions; this might bo duo to mix rd oxidation statos similar to tho situation found for the highor prasoodymium oxido by Marsh(46).) Both of thoso invostigators havo advancod tho hypothosis that it is a "thorid"scrios, i.c., that the first $5 f$ cloctron cppoars in the first cloment boyond thorium, namely protsctinium.

Zachariason has used the $x$-ray diffraction mothod to dotormino the moloculnr structures of a groat number of compounds of thorium, uranium and the transuranium clomonts. All of those moasurcmonts 
point toward the filling of the sf sholl sinco anclogous compounds aro found to bo isomorphove, ind Acating thet the succossive oloctrons aro addod in such a way (i.o., to an inncraholi) as to allow tho onalogous compounds of succossive. olomonts to heve idontical moloculan structuros. Thus, gachariason(47) pinds that procticolly all o: tho various holido typos shorn in Tablo II abovo hevo isomorphous structuros: for cxamplo, all mombors of tho group $\operatorname{Rh}_{4}-T T_{4}-\mathrm{P}_{4}-\mathrm{PuT}_{4}$ are of identical structure typos, II mombors of the group $\mathrm{UF}_{3}-\mathrm{NP}_{3}-\mathrm{PuF}_{3}-\mathrm{Am}_{3}$ aro also isomorphous with cach other, and the some is truo for the group TCI $3-\mathrm{NpCl}_{3}-\mathrm{PuCl}_{3}-\mathrm{ImCl}_{3}$

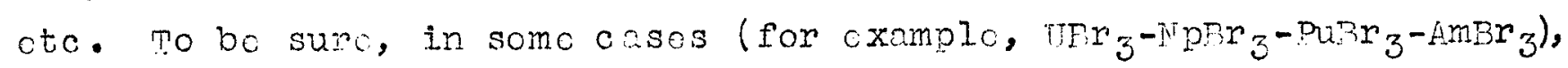
thore is a chango in stmeturo typo in procooding up tho sroup, but this is to bo cxpotod on the basis of the controction which takos placo, and is cntiroly consistont with tho acidition of tho succosivo oloctrons to tho 5 f sholl. zachariason(47) has usod thoso structuro data to calculato ionic radii and thoso racii show a prosrossivo dccroaso in sizo with incronsing atomic numbor in a monnor quito an logous to tho woll known "Icnthanido contraction" obscrvod with tho ropo oorth olomonts, tho compounds of wich aro in turn isomorphous with the corresponding compounds of tho actinido olomonts. In ondor to furthor illustrato tho so considcrations the following table (Tablo $V$ ) cives the ionic radii of a number of the actinide and Irnthenido olomonts $(47)$. 
UT, $2 I-102$

$\operatorname{Dngo} 22$

\section{TARLT V}

Ionic Radij of Actinido and Lanthanide Floments

\begin{tabular}{|c|c|c|c|c|c|c|c|}
\hline \multirow{2}{*}{$\begin{array}{l}\text { No of } 4 f \text { or } \\
5 \text { f Iectrons }\end{array}$} & \multicolumn{4}{|c|}{ Actinido Sories } & \multirow{2}{*}{\multicolumn{3}{|c|}{ Lanthanido Sorios }} \\
\hline & \multicolumn{2}{|c|}{ III stato } & \multicolumn{2}{|c|}{ IV stato } & & & \\
\hline 0 & $\mathrm{AC}^{+3}$ & $1.11 \mathrm{~A}$ & $\operatorname{Th}^{+4}$ & $0.95 \mathrm{~A}$ & $\mathrm{La}^{+3}$ & 1.04 & \\
\hline 1 & $\left(T h^{+3}\right)$ & $(1.08)$ & $\mathrm{Pa}^{+4}$ & $(0.91)$ & $\mathrm{Co}^{+3}$ & 1.02 & \\
\hline 2 & $(P+3)$ & $(1.06)$ & $U^{+1}$ & 0.89 & $P r^{+3}$ & 1.00 & \\
\hline 3 & $\mathrm{v}^{+3}$ & 1.04 & $N p^{+4}$ & 0.89 & $\pi d+3$ & 0.99 & \\
\hline 4 & $n p+3$ & 1.02 & $P x^{+4}$ & 0.86 & $61^{+3}$ & $(0.99)$ & \\
\hline 5 & $\mathrm{Pu}^{+3}$ & 1.01 & $\mathrm{Am}^{+4}$ & $(0.95)$ & $\mathrm{Sm}^{+3}$ & 0.97 & \\
\hline 6 & $\mathrm{Ar}^{+3}$ & 1.01 & & & $\pi u^{+3}$ & 0.97 & \\
\hline
\end{tabular}

I. Mognctic Suscoptibility Data. Manotic suscoptibility mossurcmonts on compounds of thr hosviost olomonts icioally should load to tho rosultant monetic momonts in fundamontal units and in this way give information as to the quantum statos of tho responsiblo clectrons. Actually, as cvidencod by tho raro orth cloments, tho situation is rother complox and the exact bohavior oxpoctod for tho hoaviost elomonts, on the basis of tho moscinco of oithor $5 f$ or 6 d cloctrons, cannot bo, or at loast hes not boon, prodictod. Novertholoss, such moasurcmonts should give, and indocd have given, informstion on this point.

The oniliost magnotic suscoptibility moasuromonts thet woro mado on compounds of uronium $(48,49,50,51)$ and plutonium(52) showod that those aro paramagnotic, Jot tho rosults aro difficult to intorprot quantitativoly. A. simplo qualitativo oxplanation of tho magnotic susceptibilitios of Pu(TII), Pu(IT) and Du(VI) lios in tho assumption that thoro ore fivo $5 f$ clectrons in PU(ITT) 


$$
\begin{aligned}
& \text { USTI-102 } \\
& 909023
\end{aligned}
$$

which are successivoly romovod as ono goos to tho highor oxidation statos. Thoso moasuromonts, howovor, do not load to this intorprotation as tho solo and unambiguous ono, and as a rosult must be rogardod only as boing consistont with and londing. woight to this vi or, but not giving proof of it.

Inton $\mathrm{C}$. A. Hutchison and $\mathrm{r}$. Dliott made majnctic suscoptibility moasuromonts ovor a wide rango of temperaturos on a numbor of compounds of the hocviost clemonts. In the case of uranium (IV) compounds $(53,54)$ they found that a numbor bohave in amanor similar to rasoocymium(ITI) compounds, indicating that those two Eroups of com ounds have isocloctronic structures with respoct to f olcotrons and thus haro two such oloctrons. Thoy disclosod in addition thet the tomperature depondonco of the masnotic suscoptibility of those uronium( ${ }^{i r}$ ) compounds oboys tho Curio-doiss low ovor a rango of tomperatures, and through oxtrapolation with the uso of this law thoy doducor a rosultant mosnetic momont vory closo to that cxpotod for two foloctrons. They also concludod that the crystal finlds produco moro pronouncod porturbing offocts in this caso then in the corrospondire caso involving $4 f$ olotrons. Thoir moasuromonts $(54)$ on ncptunium( $(T)$, which is isooloctronic with uranium(IV), also indicatod tho prosonco of tro i clectrons bero.

$J \cdot J$. Howland and M. Calvin $(55)$ bavo moasurer tho magnotic suscoptibilitios of tho cations of uranium, noptunium, plutonium, and amoricium in most of thoir stablo oxidation statos. In order to account consistently for tho obsrrved valuos of tho magnetio suscoptibility, the contral ntom must bo assumod to hove olectronic configurations (boyond the radon structure) of the type 


$$
\begin{aligned}
& \text { UPI }-102 \\
& \text { Paso } 24
\end{aligned}
$$

( $(5 f)^{1-6}$ : for oxamplo, $M p(V I)$ corrosponds to the structuro $5 f$, $\mathrm{U}(\mathrm{IV}), \mathrm{Np}(\mathrm{V})$ and $\mathrm{Pu}(\mathrm{VI})$ to $5 \mathrm{f}^{2}, \mathrm{~Np}(\mathrm{IV})$ to $5 \mathrm{f}^{3}$, $\mathrm{Pu}(I V)$ to $5 \mathrm{f}^{4}$, Pul(III) to $5 f^{5}$ and $A m(I T I)$ to $5 f^{6}$. Tho exporimontal offoctive magnotic moments aro in the cxamplos of two, throe, and four olcetrons lower than would bo oxpoctod for the lowost clretronic statos prodictod by Irund's rulos for $L-S$ coupling; bocauso tho spin-orbital interaction is very strong in hoavy atoms, other statos wich bolong to tho lowost group in $j-j$ coupling on lic doop onougin to be significantly populated at room tomporaturc. For the configuretions $5 f^{1}, 5 f^{5}, 5 f^{6}$, and $5 f^{7}$, hovevor, no such complicotion oxists; cithor atomic coupling schome loads to only ore, the samo, low lymb state.

F. Spectroscopic Iata. Spectroscopic ovidonce also londs support to the actinide intorprotation. C. C.Kioss, C. J. Humphroys and D. T. Laun $(56,57)$ investigatod tho spoctrim of uranium atoms and tho $y$ gavo the intoprotation that the oloctron configuration of tho lowost stato of noutral uranium is $5 \mathrm{f}^{3} 6 \mathrm{~d}^{2} \mathrm{~s}^{2}$ (boyond radon), a configuration which fits in vory woll sinco uranium is the thire clomont in tho scrios. othor work by p. Schuurmans and co-workors $(59,59)$ on the spoctrum of gasoous $U(I I)$ and $T(I)$ has givon rosults mich aro consistent with this struoture for thr noutral uronim atom. Spcctroscopic ovidonco that thorium possossos a ground stato analogous to that of corium also indicatos that tho charcotoristic confisuration for uranium could involve throe sf cloctrons. othor obsorvitons $(60,61,62)$ mado on tho gascous $T h(I I)$ spcotrum indicate that the $5 f$ is very close to the 6d olectron in binding onrgy in this atom. $H$. Russol $I^{(63)}$ has made a comploto analysjs of the x-roy data for 


\section{JCRI-102 \\ page 25}

radium, thorium and uranium and has concludod that the $5 \hat{f}$ lics Iowor then the $6 \mathrm{~d}$ Ic vel and that the $5 f$ shell bogins to fill at thorium.

T. S. Tompkins and M. Prod ${ }^{(64)}$ havo mado a qualitatito comporison of the cmisstion spoctro of the rotiniclo and tho lanthanico lemonts. They found such a strong nology betwoon tho avorage intonsity of tho linos in the casc of croricium cund curopium that it sooms safo to conclude that those hrvo similar oloctronic structures in the mound states. This then indicetes the conficuration $5 f^{7} 7 \mathrm{~s}^{2}$ for the gascous stom of crarricium.

ITI. Corroletions snd Doductions

A. Iloctronic configurations. The following table (Toblo VI) givos what appocrs to bo the onfiguration or the bost prociction for the configuration (boyuni the radon structure) of tho cround stato of the noutral gascous atom for cach of tho cicments actinium to curium inclusivo. The trond in tho chomical proportios, with its implication that tho $5 f$ bocomos progrossivoly o? lomor cnorgit comporod to the Ed lcvol as the atomic numbor incroasos, is usor as an aic in molning the prodictions. The configurations $(65,66)$ (boyond xonon) of the corrosponcing noutral raro oarth oloments ono givon fon comp rison. Tho fround statos givon for corium and proscodymium aro thoso prodictod $(65,66)$ on tho bosis of the rocontly determined ground statos of the sinely ionizcr atoms (67), and thet of oloment 61 is obtainod by intorpolntion, anc as a consoquoneo thess are subjoct to somo doubt. Tho ground statos givon for roodymium $(53)$, scmirium, curopium and gadolinium aro those spoctroscopicall dotomincd $(67)$ and shomld bo considorod as woll ostcblishod. 
UT $I-I 02$

Page 26

TAFIT: TI

Suggested Plectron configurations (Moronr padon r. nd yonon)

for Cascous Atoms of Actinide and Tontbonido Tlements

\begin{tabular}{|c|c|c|c|}
\hline $89-A C$ & $6 d 7 s^{2}$ & $57-I ?$ & $506 s^{2}$ \\
\hline $90-\mathrm{Th}$ & $5 f 6 d^{2} s^{2}$ or $6 d^{2} 7 s^{2}$ & $58-C 0$ & $4 f^{2} 6 s^{2}$ \\
\hline 91 -Pa & $5 f^{2} 6 d^{7} s^{2}$ or $5 f 6 d 7 s^{2}$ & $59-\operatorname{Pr}$ & $4 f^{3} 6 s^{2}$ \\
\hline $92-\mathrm{T}$ & $5 f^{3} 6 a 7 s^{2}$ & $60-N d$ & $4 t^{4} 6 s^{2}$ \\
\hline $93-\pi \mathrm{p}$ & $5 f^{4} 6 d 7 s^{2}$ or $5 f^{5} 7 s^{2}$ & 61 & $4 f^{5} 6 s^{2}$ \\
\hline $94-\mathrm{Pu}$ & $5 f^{5} 6 \mathrm{~d}^{7} \mathrm{~s}^{2}$ or $5 \mathrm{f}^{6} 7 \mathrm{~s}^{2}$ & $62-3 m$ & $4 f^{6} 6 s^{2}$ \\
\hline 95-Am & $5 f^{7} 7 s^{2}$ & $63-7 u$ & $4 f^{7} 6 s^{2}$ \\
\hline $96-\mathrm{cm}$ & $5 f^{7} 607 s^{2}$ & $64-\mathrm{Cl}$ & $4 f^{7} 5 a 6 s^{2}$ \\
\hline
\end{tabular}

It should be pointed out that it would bo cntircly consistont from tho point of viov that we cre drolins horo with a sorjos of actinido olomonts if it should oventually bo found thet thore are no $5 f$ clectrons prescnt in thorium (or protactinium). It is quito possiblo on the basis of prosont ovidonco that protactinium, or ovon urnnium, might bo tho first to havo $5 f$ oloctrons. It socms quito likoly, howovor, that oloctrons will bo placod in tho 5 fholl osrlior in the series than uranium and that protactinium will havo at loost onc. An csscntial point is that curium dofinitoly sroms to havo sovon 5 f oloctrons and clomont 103 piobably would havo fourticon $5 f$ oloctrons.

In the case of somo of tho oloments in the sonics it may bo difficult to assign clectrons to the $5 f$ or 6 d shclls sinco tho 
UT, RT,-102

Paeo 27

cnorgy nocossary for tho shift from one shcll to the other may be within the range of chomical binding cnorgios. The doctron confisuration mey diffor from compound to compound or cven with tho physical state of a givon compound. Moroovor ono cortainly cannot bo suro that the configuration of the ascous atom, for oxomplo, will corrospond to that of tho compounds or of tho hydratoc ions in solution. In tho coso of tho lanthanidos, in iact, tho confisuretion of the gasoous atom has in gonoral only two olcctrons (boyond the zenon stmucture) outside of the $4 \mathrm{f}$ sholl, athough the procominent oxidation stato is cortainly tho III stato. Sinco tho oncrgy djfforonco botwoon such far outlying lovels as the $5 f$ and 60. Sholls is rather smell and since rosonanco offocts should bo rethor Inigo, thoso may procomineto in dotormining that a composito cno:gry lovol lics lotost. Thus some of the so olcmonts could possibly constitute whet might moro propely bo callod $5 f-6 d$ rango in this sorjos, rothor then a part of a totally $5 f$ transition group.

The ovidence that hos cocumulntod so far scoms novortholoss to point to lowor oncrgios for tho $5 f$ comporod to tho 6d Iovols for the comounds of the olcment, as carly as uranium in this sorios. It is in the caso of tho olomonts thorium and protactinium whore tho rolutivo crorgy positions of those lovels is as yot most uncortain. As in tho othor transition sorios, the relative enorgy lovel of tho sholl which is undorgoing tho filling process bocomes lover as the successive cloctrons ano addod, and by tho time amoriciam and curium, and prosumbly the subsocucnt mombors of tho scipos, are roched tho 5 scoms clocnly to bo dofinitoly of lowos onorgy than tho 6 ahcll. It is not possiblo to placo 


$$
\begin{aligned}
& \text { UCPL - } 102 \\
& \text { PAgO } 23
\end{aligned}
$$

the electrons in neptunium na plutonium with consjdence end hence in Tablo $v$ the altornative structuros $5 f^{5} 7 \mathrm{~s}^{2}$ and $5 f^{6} 7 \mathrm{~s}^{2}$, respectivoly, for gasoous neptunium and plutonjum are sugrested in rocognition of the possibility that alroady with thoso olemonts tho $6 \mathrm{~d}$ sholl is not occupiod.

P. Possible Doductions without Data on Trensuranium Elemonts. Althouih it is tho information on tho transuranium clomonts that has bocn docisive in cnabling us to como to tho present vicw concorning the electronic structure, or moro proporly spoking, tho position in the poriodic tablo of the heaviost clomonts, it is intoresting to conjccturo, in retrospoct, cbout tho possibility of having crrivec at a similnr conclusion without this information. Actually thoro has boon much information about actinium, thorium, protactinium and uranium, espociclly about tho lattor, which pointod in this diroction. As montioned bove, the ro is tho similanity among tho motals of these clomonts vith rospect to olectropositivo charoctor. In addition, the molting point of uranium motal secms to rolate it moro to tho immodiatoly procoding olomonts than to tungston and molybdonum. Tho cnalogy of uranium to ncodymium with rospoct to lisht absorption by tho tripositivo ions and the spectroscopic ovidence for a cround stato of tho Gascous uranium atom jnvolving throc $5 f$ clcotrons has a lroady boon montionod.

Uranium diffors consictoraby from tungston (and molybdonum) in tho cbomjstry of tho lowor oxidation states ind, in fact, uranium(III) has gront similarity to the tripositivo raro carth olomonts and actinium, whilo urunium(IV) rosombles thorium and corium(IV). Thus uronium(IIT) and uranium(IV) nro not acidic in 


$$
\begin{aligned}
& \text { TrPL-102 } \\
& \text { P0.30 } 29
\end{aligned}
$$

cinractor, do not tond to form stions complox ions in solution, have fluoridos which cro insolublo and isomorphous with the fluorides of the rano oarth comonts onc havo othor halidos with crystal structuros which aro in gonoral isomonplous with the corrosponding rare carth halidos. on tho othom hand, tungston(III) and tungston(IV) oxist in cquoous solution prodominantly as strong complox ions; for oxamplo, tungston(III) has a strong chloride complo $x$ ion and tungston(IV) forms strons fluoride and cyonido complex ions. In this conncction Thompson(63) has pointcd out

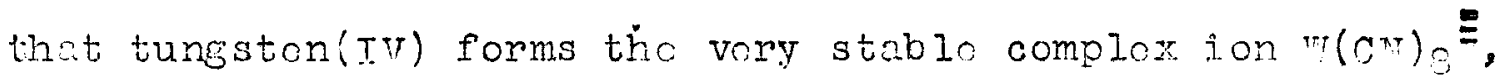
With tho stablo confieuration of oightonn outor clectrons, whilo uranium(IV) posscssos no significant tondoncy to form an analogous complox oranide ion 2.5 would sumely bo oxpoctod if uranium possossod tho same outrir olrotronic structuro as tungston. Although molybdenum dioxir and tungston dioxido havo isomorphous crystal stiuctures, tungston dioxide and uranium dioxido do not, whilo uranium dioxido, thorium dioxido and corium dioxido all do possoss isomorphous structuros. It is intornsting to noto that: athough uranium is not associatod with tungston in minorals, uranium and thorium mincrols practically always hovo the raro carth cloments associstod with thom and tho raro oarth minorals practically alwajs contain uranium or thorium.

Argumonts on the basis of the scanty ovidonco from the chemical proportios of thorium and uranium alono havo boon givon by othons, including villar $(13)$ and more rocontly D. T. Stodman (69), fa a $5 f$ typo transition scrios in tho hoaviost cloments, boginning with thorium.

C. Position in Periodic gable and Nomenclature. A mothod 


$$
\begin{aligned}
& \text { UCPI-102 } \\
& \text { Daso } 30
\end{aligned}
$$

of prosonting the cotinido clomonts in the periodio tablo is shom in Fis. 2. Toro aro shom tho fountoon olomonts of atomic numbors 90 to 103 inclusive, with ontinium (olomont 39 ) as the prototypo listod as a sorios bolow, and in $=$ mannor similar to, the common listing of the fourtoon rano oarth olomonts of atomic numbors 58 to 72 inclusivo, for which lenthanum (olomont 57) is tho prototype. It is not proposod that this particuler form of the poriodic tablo has any moro morit than any of a numbor of others which placo thoso olomnts in positions homologous to tho rano caitl olomonts, sinco it is obvious that they can bo analogously placod in a numbor of othor typos of toblos or charts. Tho loments 90 to 96 inclusivo conld bo listod soporatoly bolow the 50 olomonts in recognition of the rosomblance of tho first fow of those to $5 d$ cloments. This appoars to bo undosirablo howovor sinco tho last mombors of this group bon no such rosomblanco and it is probably impossiblo to drav a lino as to just where the rosemblance onds.

As mentioned above, the important point is the prosonco of soven $5 f$ clectrons in stablo, tripositivo curium (clomont, 96), making this olcmont vory actinium-like. A sorios of "thorido" olamonts, for cxomplc, mould imply stable IV oxidation statos in elomonts 95 and 96 , with tho prosonco of scvon 5 f oloctrons and tho IV stato oxclusively in olcmont 97. A sorios of this typo socms to bo mied out by the now rnown impossibility of having amoricin in solution in the IV statc and by tho appront noncxistonoo of any oxi action state other than TIT in curium. Morcovor, the III state of uranium would bo surpising on this basis sinco this olcmont would bo the socond mombor of a "thorido" or 


$$
\begin{aligned}
& \text { UTCRI - } 102 \\
& \text { P030 } 31
\end{aligned}
$$

"IV oxication statc" sorios.

Tho Eroup probably could hove bocn just as noll doscribod by somo other torm such as "curido scrios", rathor than "sctinido", which is dorivod from analogy vith tho torm lonthanido. Another possibjljty would bo to uso a namo ana logous to "roro carths" . A suestion horo would bo "synthotic oarths" in vicw of tho synthotic sourco of aII oxcept tho first throc mombors. (TVon among those, the synthotic production of pai3l according to $\mathrm{Tr}^{230}(\mathrm{n}, \mathrm{r}) \mathrm{Th}^{231} \longrightarrow \mathrm{Pa}^{231}$ and of $\mathrm{U}^{233}$ from $\mathrm{Th}^{232}(\mathrm{n}, \mathrm{r}) \mathrm{Th}^{233}$ pa $233 \longrightarrow \mathrm{T}^{233}$, accounts for the bost sourcos of important isotopos of protactinium and uranium; tho best sourco of actinim also comos from pilc noutrons, by the rocotions $\mathrm{Ra}^{226}\left(\mathrm{n}, \mathrm{r}^{\circ}\right) \mathrm{Ra}^{227} \longrightarrow$ $\left.\mathrm{Ac}^{227} \cdot\right)$

Irrospetive of the namo which usace will finally assign to this sroup of clcments, howover, it socms that the outstanding charcateinstics of tho group, nomoly tho "cka-gadolinium" cheractor of curium (and tho prosumed "oke-lutecium" character of oloment 1.03), togothor with tho rocularly incroasing trond toward actinium-liko charactor in going from thorium to curium, aro bost roprosontod by listine thoso clomonts in corrospondirs positions undor the raro oarth cloments. (Somo spatial classific tions $(70,71$ ) of the olomonts havo appoarod rocontly in which those clomonts, starting with thorium as tho homologuo of corium, aro listod ns tho chonical homolosucs of tho raro carth olcmonts, but tho roason in thoso casos aporars to bo moinly connoctod with tho aymmotry f f, and the casc of moking, such an arrangoment.)

D. Probjotod proportios of Transcurium lomonts. It is intorosting to spoulato about the chomical propertics of tho 
UCRI -102

Pago 32

undiscovorod oloments boyond cunium (atomic numbor 96). The immodiatoly following sovon olomonts, that is, olomonts 97 to 103 inclusive, should constitute tho socond half of this rare onrthliko transition group. It appoars likoly that tho addod oloctrons in prococding up this scrios will bo placod in a $5 f$ sholl of dofinitoly lowor onorgy than tho 60 sholl. Tloment 97 will probably havo a IV as woll as c. ITT oxiration statc and in viow of tho lower binding onergy of the $5 f$ as comparcd to the af cloctrons it should bo somowhat casicr to oxidizo olomont 97 (cka-torbium) to this IY stato than is tho caso for terbium. corrospordingly, it might bc somewhat onsirr to oxidizo olomont 98 (oka-dysprosium) to the IV and $V$ oxidation statos than is tho caso for dysprosium, for which, in fact, oxidation abovo tho III stato is practically imposiblo. Toward tho ond of tho srios, oloments 102 and 101 should bo capeblo of boing roduc od to tho II oxidation stato, analogously to yttorbium and thulium, whilo oloment 103 should bo analogous to lutocium with respoct to the completo stability of tho III stato.

Tiemont 104 should continue with the filling of the $6 \mathrm{~d}$ sholl and bo a truo oka-hofnium. Aftor tho filling of tho 6 d sholl in the following cloments thore might bo addition to tho $7 p$ sholl with the attainment of the raro gas structure at olement 118 . 
TICPI - IOZ

Pago 33

Roferoness

1. For cxamplo, (o) Latimer, T. M., and J. I. Hildobrand, Roforonco nook of Inorganic Chomistry, p. 519. Macililan Company, Now York, 1940; (b) Tarlor, H. S., and S.classtonc, Troatisc on Physical Chomistry, Volumc Ono, p. 298. N. Van Nostrand Compony, Inc., Now Yorls, 1942. (c) Handbook of Chomistry and Physics. Chomical zubber Publishing Company, Cloveland, Ohio. (d) Pichtmeyor, F. K., and $D$. H. Kennard, Introduction to Modem Physics; p. 707. Morraw Hill Book Company, Inc., NT W York, 1942.

2. Eohr, I., Phil. Mag., 26, 1, 476 (1915).

3. Bohr, N., Iaturo, $112,29(1923)$; see also $N$. Bohr and $D$. Coster, 7. f. Physik 12, 342 (1923).

4. Suguira, Y., and H. C. Uroy, KGI. Dansko Vidonskb. Sc Iskab, Math.-Pys. Modd., I, No. 13, 3 (1926).

5. MoLoman, J.C., A. R. McIny and T. G. Smith, Proc. ?OJ - Soc. of Iondon, Snrios A, 112, 76 (1926).

6. Dushman, S., Chcm. Rov. 5, 137 (1926).

7. Karapotofr, t., J. of Eranklin Instituto 210, 609-623 (1930).

8. Ta-You-Mu and S. Goudsmit, Phys. Rov. 43, 496 (1933).

9. Crosso, A. Von, J. Am. Chom. Soc. 57, 440 (1935); see also Ber. $61,233(1928)$ and J.Am.Chem.Soc. $52,1742(1930)$.

10. Ouili, I. I., Chom. Rov. 23, 87 (1938).

11. Mayor, M. Gooport, Phys. Pov - 60, 194 (1941): see also R. Daude 1, Compt. rend. 217, $396(\overline{1943)}$.

12. Porrin, T., Grains de Matirro ot do Lumidro, II-30, Horman and oic, Paris $(1935)$.

12a. Ruty, R., Rev - gener. Sci. pur. appl. 33, 671 (1927).

13. Viliri, $A . E$. J. of Chem. A. 19, 329 (1942); Ann. Acad. Dinsji. Soi. 1251 (1940).

14. Goldschmidt, V. M., "Travoux du Congrès Jubilairo Mondolócv", II, 387 (1937).

-5. Zachariason, H. H., Roport Gr-1518, p. 3, March, 1944, and Roport CII-1807, Juno, 1944.

16. MoMilian, I. M., and P. H. Abolson, Phys. Rov. 57, 1135 ( 1940 ).

17. Starko, K., Z. AnorE. allgom. Chom. 25I, 251 (1943).

18. Bodrocg, C. C., Maturwiss. 31, 490 (1943).

19. Strassmann, Fe, and 0 . Hahn, Naturwiss 30,256 (1942). 
TCRI -102

Dar. 34

20. Soaborg, . T., and A. C.Ml, Roport A-135 and Roport No. ( ) (March 19, 1942); J.Am.Chom. Soc., 70, 1128 (1948) (Daper ritton March 19, 1942).

21. Scaborg, G. T., Rcport MTC-TS-353 (TulJ, 1944), Roport. CK-1968 (A-2345) p. 55 (JuIY 17, 194t); Chcm. Ang. News, 23, $2190(1945)$.

22. Intimer, N. M., "Tho oxidation statos of tho Tiloments and Thoir Potcntials in Aquoous Solutions", Prontico-Holl, Inc., Now York $(1938)$.

23. Soc, o.g., for uranium, Survoy volume on Jranium Chomistry, Volume I; for noptunium, PPP Vol. $14 \mathrm{~A}$, chaptor $\mathrm{YV}$; for plutonium, PPR Vol. 14A, chapter III for an joium PP? Vol. I.4R, JTo. $19 \cdot 2$.

24. Mhompson, S. G., L. O. Morgan, R. A. Jamos and I. Porlman, PPR VOI. 14B, NO. 19.1 (1946).

25. Wcrnor, I. B., and I. Porlman, roportod in Tniversity of California Radiation Iaboratory (chomistry Croup) Progress Roport RL 4.5.46 (Juno, 1946).

26. Vornor, I. B., and I. Porlmen, roportod in Jnivorsity of California Reciation Laboratory (Chomistrit (roup) Progross icport FC-30 (August, 1947 ).

27. Firicd, S., and A. F. Florin, Private communication (octobor, $1947)$.

28. Zc.chonicson, T. H., PP? Vol. 14A, ohaptor YY (MUC-FVYZ-I75) $(1946)$.

29. Mcculloueh, J. D., roportod in Univorsity of California Radiation Laboratory (Choristry Group) Progross Roport RI 4.5.56 (April, 1947).

30. Marsh, J. K., J. Chom. Soc., 1946, 15.

31. Prandt, w., and G. Riodor, Z. anore. allgom. Chom•, 238, $225(1938)$.

32. Trice, s, roportor in ANI-MMM-24 (JulT, 1946).

33. Nostrum, T., roportod in trivorsity of California Radiation Laboratory (chomistry Group) Procross zoport RL -4.5 .49$ (Soptcmbor, 1946); UT, RI -46 (J口n., 1948).

34. For tho rare carth motal donsitics, son c.e., Yost, D. M., T. Russoll, Jr., and C. S. Forner, "The Paic Tarth Eloments and their Compounds", John Wilcy, Inc., 1947, p.2.

35. Tor unanium donsity, seo o.0., $\mathrm{C}$. Jacob anci B. - Varren, J.Am. Chom. Soc. 59, 2589 (1937) or Battollo Momorial 


\section{UCRI -102 \\ Pago 35}

Instituto Rnport CT-2144, p. 218 (s=ptombon 1, 1944); for noptunium, PP? Vol. 14A, chaptor YV; for plutonium, "Tho Chomistry and Motallurgy of Plutonium" (Jditod by $\mathrm{C}$. A. Thomas and J. C. Warnor), Docombor, 1944, pp. 381-332; for ancricium, Univosity of California Radiation Lahoratory (Chomistry Group) progross Roport RL-4.5.49 (Sopt., 1946) and TOTI-46 (Jan., 1948).

36. Cold schmidt, V.M., Portschritto dor Mincralogie, TristalloGraphio und Potrographio 15, 73 (1931).

3r. Tphraim, F., and M. Mozonor, Holv. Chim. Acta 16, 1257 (1933) and J. Indian Chom. Soc., Ray-Momorial Vol., p. 243 $(1933)$ :

38. Tor uranium, Howland, J.J., "Absorption spectro of Tiraniun(ITT) and Tranium(IV) in MOlar HYdrochloric Acid", M.F.T.S., Vol.'IIB; for noptunium, Mrgnusson, I., T. J. L?Chepol1o and J. C. Tindman, CN-3053, Junc 1 , 1945; for plutoniurn, Findmon, J.C., and $\mathrm{J}$. P. Amos, CN-3053, Junc, 1945, for ancricium, cunningham, B. B., pp? Vol. 14B, No. 19.2 (1946); for curium, Worncr, I. P., and I. Porlman, Privato conmunication (ootobor, 1947).

39. Prand tl, W., anr K. Schoinor, Z anorg allgom. Chom. 220, $107(1931)$.

40. Stomert, D. C., Privato communication (Jonuory, 1948 ).

4I. Ischtz, P. M., axd C. W. Parker, Ropont CNI-37, p. 114 (Apri1 16, 1948).

42. Frood, S., and F. J. Loitz, Jr., Rcport CNI-6, p. 46 (Soptombor-Novomber, 1947); Roport at symposium on chomistry of Transuranium Elomonts, 1948 Spring Moting Am. Chom. Soc., Chicago, Illinois.

43. Coldschmidt, V. M., Fra Fysikkons Vordon (Norsk Fysisk Ticsslrift) 3 , $179(1941-42)$.

44. Zacharioson, W. T, MTC,-MTZ-156 (Novombor 3, 1945).

45. Tompleton, N. H., roportod in Univorsity of Californin Radiation Laboratory (Chomistry croup) Trogross inport UCRI, 15 (Novombor, 1947 ).

46. Marsh, J. r., J. Chom. Soo., 1946, 15.

47. 7achariason, W. H., PPR 14i, Chaptor XY (NUC-TWZ-175 (1946)) for 0.11 cxcopt cumolicium compounds; for tho lattor and including actinium, sco Zacianiason, W. H., ANI-FWHZ-I42 (Novombor 19, 1947).

48. Lowronce, R. W., J. Am. Chom. Soc,, 56, 776 (1934). 
TCZI -102

Pago 36

49. Haraldson, H., and R. Eakkon, Naturwiss. 28, 127 (1940).

50. Bommer, H., Z. anorg. $0116 \mathrm{~cm}$. Chcm. 247, 249 (1941).

51. Sucksmith, ", phil Mrgg 14, 11.15 (1932).

52. Calvin, M., Rrport CK-24II (Octobo: I, 1944).

53. Tutchison, C.A., Jr., and N.Tlliott, Bulletin of tho Amoricon Dhysical socioty, Vol. 22, No. 6, Abstract D9 (1947).

54. Futchison, $G \cdot A \cdot, J r .$, and $\mathrm{I}$. Tlliott, Reportod at smposium on chomistr of Transuranium loments, 1948 spring looting $\mathrm{nm}$. Chon. Soc., Chicago, Illinois.

55. Flomland, $J \cdot J$., and $M$. Calvin, Roportod at Symposium on Chomistry of Transurenium Iements, 1948 sprins Mcoting Am. chom. Soc., Chic aso, Illinois.

56. Kioss, C.C., C.J. Kumphroys and D. D. Iaun, Roport (A-I7A7) National Burrau of Standerds, Tobruary 7, 1944. "Proliminary ncscription and Aralysis of the spcotrum of Noutral Uranium fitorns "

57. Tioss, C.C., C.J. Humphreys and D. D. Loun, J. Ros. National Burcau of Standards, 37, Zosourch paper No. 1729 (1946); J. Optical Soc. Am. 36,357 (1946).

58. Schuurmans, P., Physice 11, 419 (1946).

59. Schuurmans, P., J. C. Van Don Bosch and N. Dijkwol, Physica 13, $117(1947)$.

60. McNolly, J. R., Jr., J. Optical Soc. fm. 35, 390 (1945).

61. dopruin; T. I., D. Schuumans and P. F. A. Tlinkonborg, Z. Physik 121, 667-78 (1943).

62. doBruin, T. I., D. . A. KIinkonborg and P. Schuurman, 7. Physik 122, 23 (1944).

63. Russoll, H., Jr., In-145 (Soptombor 24, 1944); U. S. Atomic

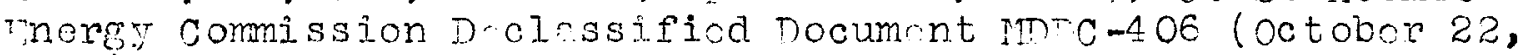
19461 .

64. Tomplins, F. S., and M. Pred, Privato Communication (March 3, 1949).

65. Yost, D. M., 4. Russoll, Jr., and C. S. rarnor, "Tho RaroEarth Elcrents and Thoir Compounds", wiloy, Inc., 1.917, pp. 3 and 4 .

66. Klinkonbors, P. T. A., Thysics 13, I (1947). 
UCRL -102

Pago 37

67. MoEgors, W. F., Rov. Mod. Physics 14, 96 (1942) . Toviow papor, with roforoncos to individual papors, on tho known spcetra of the rarc oerth clomonts.

68. Thompson, S. G., Privatc commication (octobor, 1947).

69. Stctman, D. T., Con. T. Rosonroh 25P, 199 (1947).

70. Dounkovsky, G. T., and S. Kavos, J. phys. radium (8), 5 , $53(1944)$.

71. Tralpain, I, J. phys. radium (3) 6, 176 (1945). 
ABSORPTION SPECTRA of the AQUEOUS TRIPOSITIVE

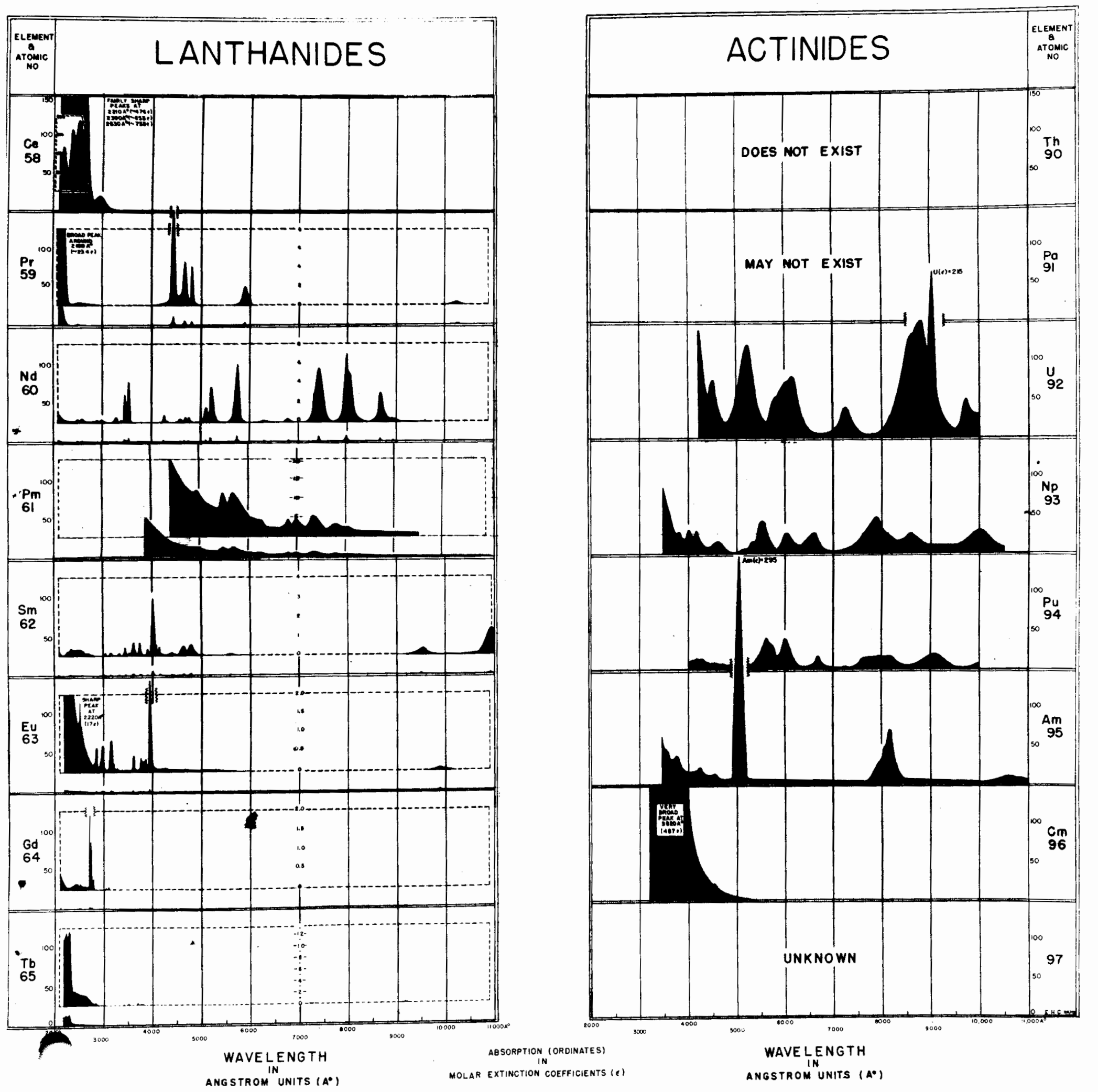

FIG. I 

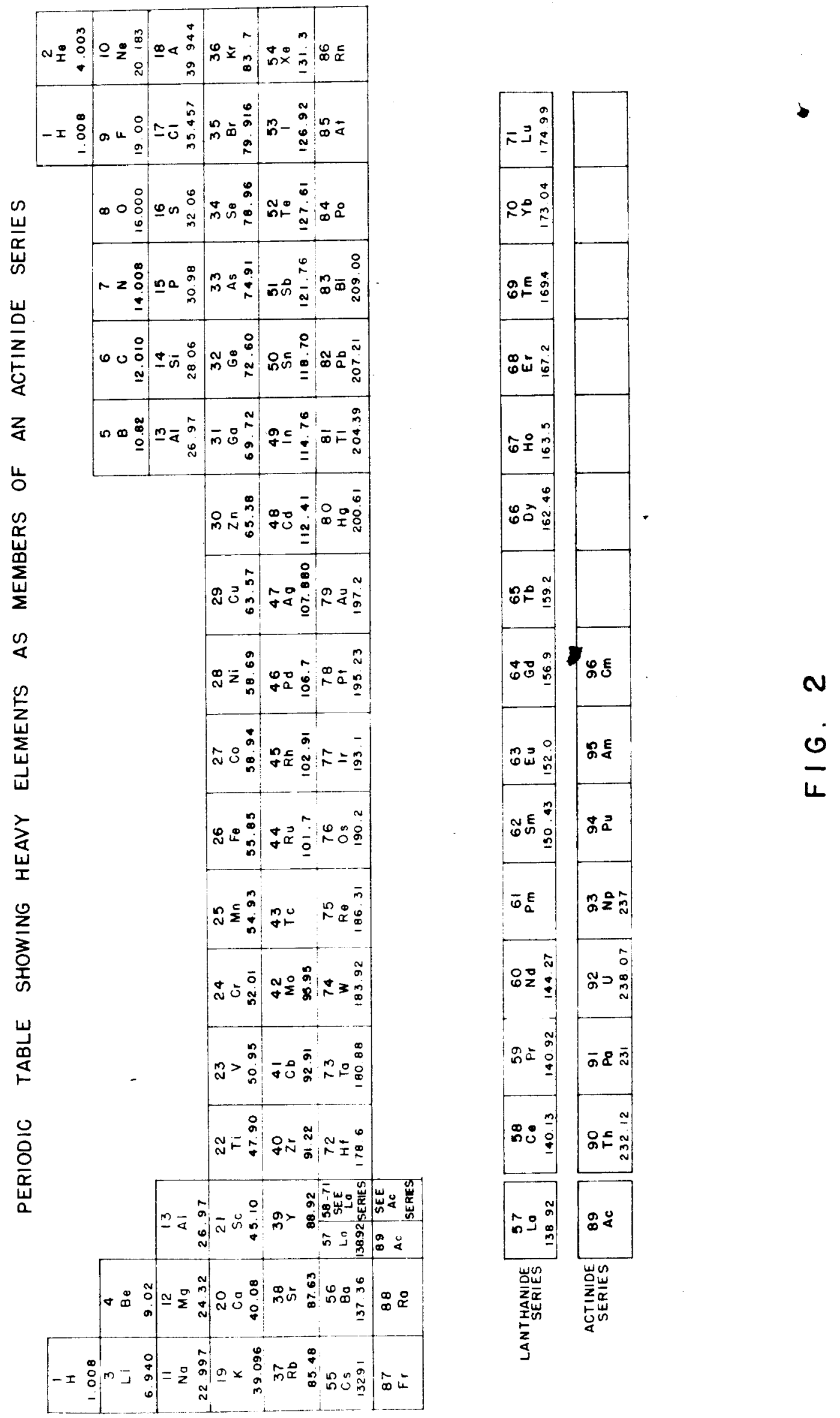